\title{
CHEMICAL CONSTITUENTS, ANTIOXIDATIVE, CYTOTOXIC, AND GENOTOXIC EFFECTS OF MISCANTHUS CAPENSIS ROOTS EXTRACT
}

\author{
IDOWU JONAS SAGBO*, WILFRED OTANG MBENG
}

School of Biology and Environmental Sciences, University of Mpumalanga, Private Bag X11283, Mbombela, 1200,

South Africa. Email: Jonas.sagbo@ump.ac.za

Received: 10 August 2019, Revised and Accepted: 09 October 2019

\section{ABSTRACT}

Objective: Miscanthus capensis (Nees) Andersson (Poaceae family) is used in traditional medicine to treat pimples, wounds, eczema, acne, and other ailments. The present study investigates the possible chemical constituents, antioxidant, cytotoxic, and genotoxic effects of the methanol extract of the $M$. capensis roots.

Methods: Gas chromatography-mass spectrometry (GC-MS) analysis was carried out to identify the chemical constituents of the plant extract. Cytotoxicity and mode of cell death toward human dermal fibroblasts (MRHF) cells were assessed using the ImageXpress ${ }^{\circledR}$ Micro XLS analysis system. Genotoxic effect toward Vero cells was also investigated using micronucleus assay. Furthermore, ferric reducing power (Ferric reducing antioxidant potential [FRAP]) and reactive oxygen species (ROS) levels in MRHF cells were used to estimate the antioxidant activity of the plant extract.

Results: The GC-MS results showed a maximum amount of bioactive components (77 compounds) with rosifoliol (33.66\%) being the major component detected. However, the extract was not toxic to MRHF cells but demonstrated anti-proliferation rather than cell death at the tested concentrations $(25,50$, and $100 \mu \mathrm{g} / \mathrm{ml})$. In addition, the plant extract also displayed non-genotoxic toward Vero cells with no significant increase in micronucleus formation at the tested concentration while a concentration dependence response in FRAP values and ROS levels in MRHF cells lines were observed indicating better antioxidant activities of the plant extract.

Conclusion: The results suggest that $M$. capensis could be a promising candidate for preventing or eradicating skin and oxidative-stress related diseases.

Keywords: Antioxidant, Poaceae, Oxidative stress, Skin.

(C) 2019 The Authors. Published by Innovare Academic Sciences Pvt Ltd. This is an open access article under the CC BY license (http://creativecommons. org/licenses/by/4. 0/) DOI: http://dx.doi.org/10.22159/ajpcr.2019.v12i12.35302

\section{INTRODUCTION}

Antioxidants play a significant role in suppressing the process of oxidation by blocking the initiation or propagation of oxidizing chain reactions. Many synthetic antioxidants such as butylated hydroxytoluene, tert-butylhydroquinone, propyl gallate, and butylated hydroxyanisole are normally used in the food industry because of their strong effectiveness in preserving lipid components from quality deterioration. However, the amount allowed in food is restricted due to toxicity and concerns about long-term health effects $[1,2]$ Recently, much attention has been focused on the development of safe and effective non-toxic antioxidants of natural origin [3]. This is due to their ability to scavenge or suppress free radicals/oxidative stress which has been associated with the pathogenesis of numerous disorders, including neurodegenerative [2], carcinogenesis [4], and cardiovascular diseases [5]. Hence, it is important to intensify in the search for effective non-toxic natural antioxidants which could eradicate free-radical related maladies in human beings and also substitute the harmful synthetic antioxidants.

Plants have long been consumed as food and contain substantial amounts of antioxidants which are more beneficial to the body. Furthermore, several plants have been reportedly used in folklore medicine for various therapeutic purposes. The use of plant as a source of antioxidant became more pertinent recently as oxidative stress was considered a major contributor to most diseases in humans and the antioxidant defense system in human was usually not enough to overcome the free radical level in the body. As such, plants have gained enormous interest as a source of antioxidants and with the potential not only to reduce oxidative stress and physiological side effects but also to diminish genotoxicity [6]. However, plants are known to have antioxidant because of the presence of several classes of phytochemicals with anti-inflammatory, anticarcinogenic, antigenotoxic, and antioxidant activities [7-9]. In addition, they are more readily accessible, more affordable and less likely to cause dependency compared to synthetic drugs [10]. Therefore, it is imperative to further explore these medicinal plants for the treatment of various diseases in humans.

Miscanthus capensis (Nees) Andersson (Poaceae family) is a hardy, evergreen, clump-forming, and large grass that has beautiful autumn colors. The clumps of leaves of the plant are about $1 \mathrm{~m}$ tall and the flowering stalks are up to $2 \mathrm{~m}$ tall and it is widely distributed in South Africa provinces such as Eastern Cape, Northern Cape, Western Cape, KwaZulu-Natal, and Free State. Conventionally, the bark or root decoction of the plant is used to treat pimples, wounds, eczema, and acne [11]. Despite the traditional usage of this plant, there is as yet no record of any scientific evidence supporting its pharmacological application. Therefore, in this study, we investigate the antioxidant, cytotoxic, and genotoxic effects of $M$. capensis roots extract in cultured mammalian cell lines (MRHF and Vero cells) using in vitro assays. In addition, detailed studies of the compounds present in this plant were determined using gas chromatography-mass spectrometry (GC-MS).

\section{METHODS}

Collection of plant materials and preparation of $M$. capensis methanol extract

The fresh whole plant of $M$. capensis was collected in Alice (Eastern Cape and South Africa) in November 2018. The plant material was 
Table 1: Chemical components of methanol extract of Miscanthus capensis analyzed by gas chromatography-mass spectroscopy

\begin{tabular}{|c|c|c|}
\hline Compounds & Rt (min) & Area $(\%)$ \\
\hline$\delta$-Eiemene & 26.753 & 0.02 \\
\hline$\alpha$-Cubebene & 27.266 & 0.31 \\
\hline Ylangene & 28.156 & 0.53 \\
\hline Copaene & 28.347 & 0.1 \\
\hline$\beta$-Cuvebene & 28.981 & 0.22 \\
\hline$\beta$-elemene & 29.076 & 0.21 \\
\hline Bicyclosesquiphellandrene & 29.939 & 0.35 \\
\hline Germacrene B & 30.796 & 0.45 \\
\hline$\beta$-Patchoulene & 31.169 & 0.02 \\
\hline$\alpha$-Cadinene & 31.274 & 0.98 \\
\hline$\delta$-Amorphene & 32.4 & 0.49 \\
\hline$\gamma$-Muurolene & 32.532 & 0.72 \\
\hline$\beta$-Selinene & 32.867 & 0.08 \\
\hline Bicyclo[4.4.0]dec-1-ene, & 33.306 & 1.3 \\
\hline \multicolumn{3}{|l|}{ 2-isopropyl-5-methyl-9-methylene- } \\
\hline Dihydroagarofuran & 33.564 & 0.8 \\
\hline Epicubebol & 34.218 & 3.48 \\
\hline$\delta$-Bisabolene & 34.802 & 0.54 \\
\hline 1-(3-Methyl-cyclopent-2-enyl)-cyclohexene & 35.001 & 0.11 \\
\hline$\alpha$-Calacorene & 35.141 & 0.33 \\
\hline$\beta$-Elemol & 35.47 & 1.08 \\
\hline Calarene & 36.141 & 1.26 \\
\hline Caryophyllene oxide & 36.635 & 0.14 \\
\hline Rosifoliol & 36.813 & 33.66 \\
\hline Humulane-1,6-dien-3-ol & 37.797 & 7.48 \\
\hline Epizonarene & 37.908 & 0.14 \\
\hline$\gamma$-Eudesmol & 38.146 & 1.51 \\
\hline Carotol & 38.387 & 5.78 \\
\hline Epicubenol & 38.508 & 0.72 \\
\hline$\alpha$-Panasinsene & 38.855 & 5.4 \\
\hline Agarospirol & 39.108 & 2.68 \\
\hline$\alpha$-Cadinol & 39.519 & 7.44 \\
\hline Isoaromadendrene epoxide & 39.779 & 1.91 \\
\hline Aromandendrene & 39.912 & 0.5 \\
\hline Cadalene & 40.165 & 0.1 \\
\hline Cypera-2,4-diene & 40.355 & 0.16 \\
\hline Valerena-4,7(11)-diene & 40.692 & 0.21 \\
\hline$\gamma$-Neoclovene & 41.187 & 0.18 \\
\hline (-)-Spathulenol & 41.329 & 0.37 \\
\hline Isoshyobunone & 41.653 & 0.11 \\
\hline 2-Hydrazino-nicotinic acid & 42.398 & 0.62 \\
\hline 1-Methyl-1-hydroxymethyladamantane & 43.166 & 0.18 \\
\hline Valerenol & 43.393 & 0.22 \\
\hline 7-(2-Hydroxypropan-2-yl)-1,4a & 43.64 & 1.57 \\
\hline \multicolumn{3}{|l|}{-dimethyldecahydronaphthalen-1-ol } \\
\hline 1H-Inden-1-ol,2,4,5,6,7,7a-hexahydr & 46.148 & 0.11 \\
\hline \multicolumn{3}{|l|}{$-4,4,7$ a-trimethyl- } \\
\hline Longifolenaldehyde & 46.728 & 0.16 \\
\hline 25-Hydroxycholesterol & 47.279 & 0.05 \\
\hline Isoxylitone A & 47.993 & 0.12 \\
\hline Duvatrienediol & 48.316 & 0.03 \\
\hline$[1,3,4]$ Oxadiazole, & 48.509 & 0.04 \\
\hline \multicolumn{3}{|l|}{ 2-amino-5-(4-fluorophenyl)- } \\
\hline Hexadecanoic acid, methyl ester & 48.872 & 0.24 \\
\hline Aciphyllene & 49.397 & 0.06 \\
\hline cis-11-Hexadecenal & 49.523 & 0.03 \\
\hline trans-syn-cis-Tricyclo[7.3.0.0 $(2,6)]$ & 49.965 & 0.07 \\
\hline \multicolumn{3}{|l|}{ dodecan-7-one } \\
\hline n-Hexadecanoic acid & 50.493 & 2 \\
\hline Oleic acid & 51.156 & 0.62 \\
\hline 4,8-Decadienal, 5,9-dimethyl- & 51.65 & 0.06 \\
\hline 4-Bromo-3-oxobutyric acid, methyl ester & 52.202 & 0.02 \\
\hline trans-Chrysanthenol & 52.559 & 0.05 \\
\hline Octadecanal & 52.767 & 0.05 \\
\hline Caparratriene & 53.264 & 0.03 \\
\hline $\begin{array}{l}\text { 9,12-Octadecadienoic acid (Z, Z)-, methyl } \\
\text { ester }\end{array}$ & 54.028 & 8.1 \\
\hline
\end{tabular}

(Contd...)
Table 1: (Continued)

\begin{tabular}{lll}
\hline Compounds & Rt (min) & Area (\%) \\
\hline 9-Octadecenoic acid (Z)-, methyl ester & 54.222 & 0.35 \\
Methyl stearate & 55.036 & 0.02 \\
9-Octadecenoic acid, (E)- & 56.137 & 2.89 \\
2-Methyl-Z, Z-3,13-octadecadienol & 57.108 & 0.1 \\
9,17-Octadecadienal, (Z)- & 57.541 & 0.05 \\
Propanoic acid, 2-methyl-, & 58.182 & 0.02 \\
3,7-dimethyl-2,6-octadienyl ester, (Z)- & & \\
7-Pentadecyne & 59.967 & 0.02 \\
Hexadecanal, 2-methyl- & 60.155 & 0.05 \\
Methyl 18-methylnonadecanoate & 60.735 & 0.03 \\
Z, Z-3,13-Octadecadien-1-ol acetate & 61.092 & 0.05 \\
Oxirane, tridecyl- & 61.092 & 0.05 \\
Eicosanoic acid & 61.27 & 0.02 \\
Octacosanol & 64.976 & 0.02 \\
11,13-Dimethyl-12-tetradecen-1-ol acetate & 65.221 & 0.02 \\
Didodecyl phthalate & 66.377 & 0.01 \\
\hline
\end{tabular}

Compounds are listed in order of Rt. Rt: Retention time

authenticated at the Giffen Herbarium from the Department of Botany, University of Fort Hare, and a voucher specimen (MC3876) was deposited at the same institution. The roots of the plant were detached from the rest after which they were air-dried for 30 days. Thereafter, the dried roots were then milled to a homogenous powder. The powdered plant materials $(60 \mathrm{~g})$ was soaked in $1000 \mathrm{~mL}$ of methanol and then placed on an orbital shaker (Labcon Laboratory Service (Pty), South Africa) for $24 \mathrm{~h}$. Thereafter, the extract was filtered and the resulting methanol filtrate was concentrated using a rotary evaporator (Heidolph Laborota 4000, Heidolph instruments, GmbH \& Co, Germany). The extract was then weighed to determine the yield (18.1\%) and then stored at $4^{\circ} \mathrm{C}$ for further studies.

\section{GC-MS analysis}

Identification of metabolites in the methanol extract of $M$. capensis was carried out using an Agilent 7890 GC system combined with an Agilent 5977A mass selective detector system with a HP-5MS column (30 $\mathrm{m} \times 250 \mu \mathrm{m} \times 0.25 \mu \mathrm{m})$. The GC-MS was operated at an electron ionization of $70 \mathrm{eV}$, ion source temperature of $280^{\circ} \mathrm{C}$, and pressure of $48.745 \mathrm{kpa}$. Helium was used as the carrier gas at a constant flow rate of $36.262 \mathrm{~cm} / \mathrm{s}$ and about $1 \mu \mathrm{L}$ sample injection was used. The oven temperature was programmed from $40^{\circ} \mathrm{C}$ (held for $1 \mathrm{~min}$ ) to $240^{\circ} \mathrm{C}$ at an increasing rate of $3^{\circ} \mathrm{C} / \mathrm{min}$. Mass spectra were acquired over $40-$ 500 amu range. Compounds were identified by matching their relative retention time and mass spectrum data of the individual compound with those of the standard known compound available in the library of National Institute of Standards and Technology.

\section{Maintenance of cell cultures}

The human foreskin fibroblast (MRHF) cells were cultured in Dulbecco's modified Eagle's medium supplemented with $10 \%$ fetal calf serum and subcultured every 2-3 days. Vero cells were maintained in DMEN (low glucose) supplemented with $10 \%$ fetal bovine serum and subcultured every 2-3 days. All cell cultures were incubated in a $37^{\circ} \mathrm{C}, 5 \% \mathrm{CO}_{2}$, humidified atmosphere.

\section{Cytotoxicity and mode of cell death}

Briefly, MRHF cells (8000 cells/well) were plated in a 96-well plate and left to attach overnight. The cells were exposed with plant extract at various concentrations $(25,50$, and $100 \mu \mathrm{g} / \mathrm{ml})$ and then incubated for $24 \mathrm{~h}$ at $37^{\circ} \mathrm{C}$ in a humidified incubator with $5 \% \mathrm{CO}_{2}$ After the incubation period, the spent culture medium was removed and replaced with $50 \mu \mathrm{l}$ of staining solution (prepared as $5 \mathrm{ml}$ binding buffer containing $50 \mu \mathrm{l}$ of Annexin V-FITC reagent [Miltenyi Biotec Annexin V Kit: Cat no 130-092052] and $2 \mu$ l of Hoechst dye solution) and then incubated for $15 \mathrm{~min}$ at $37^{\circ} \mathrm{C}$. At the end of the incubation, $50 \mu \mathrm{L}$ of propidium iodide was added to the cells and then further incubated for $5 \mathrm{~min}$ before the acquiring of the cells images by Molecular Devices ImageXpress ${ }^{\circledR}$ Micro XLS 


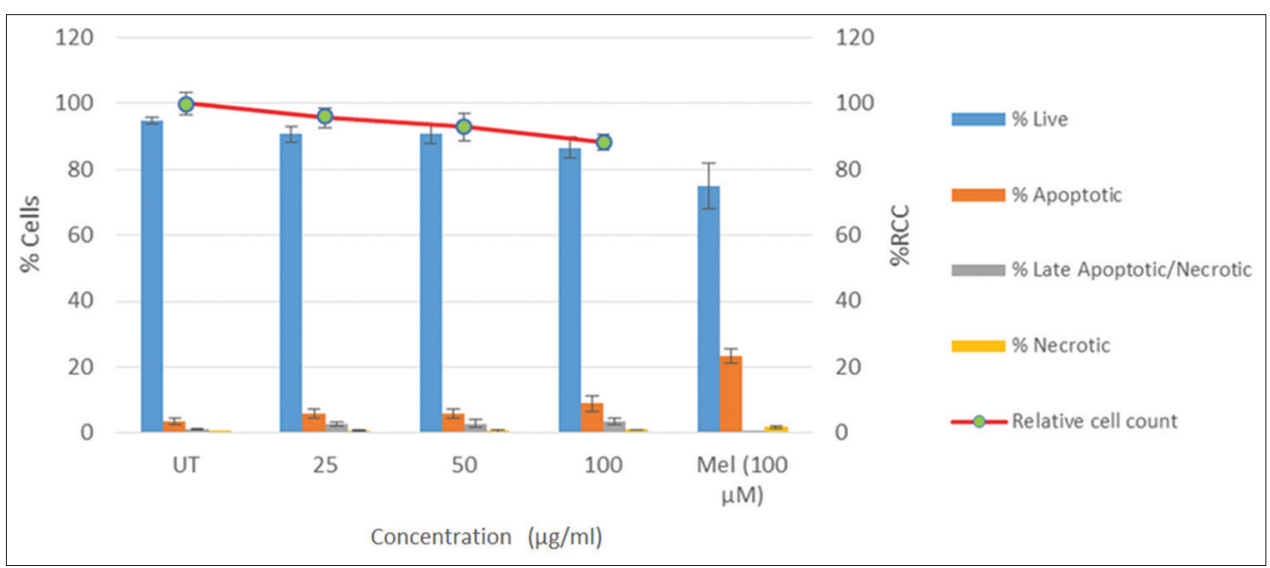

Fig. 1: Cytotoxicity and mode of cell death in human dermal fibroblasts (MRHF cells) after treated with Miscanthus capensis methanol extract. Significant difference $(\mathrm{p}<0.05)$ compared to the untreated (UT) control

microscope (CA, USA) using FITC, DAPI, and Texas Red filters and $\times 40$ objective. Thereafter, the cells images were analyzed by a MetaXpress 6 software (Cell Scoring Module application).

\section{Reactive oxygen species (ROS) levels (oxidative stress assay)}

Briefly, MRHF cells were seeded in a 96-well plate at a density of 8000 cells/well and left to attach overnight after which the cells were exposed to different concentrations of the plant extract $(50,100$, and $200 \mu \mathrm{g} / \mathrm{ml}$ ) or positive control (N-acetylcysteine [NAC], $5 \mathrm{mM}$ ). After $24 \mathrm{~h}$ of incubation, $100 \mu \mathrm{M}$ of tert-butyl hydroperoxide was added to induce oxidative stress and further incubated for $2 \mathrm{~h}$ at $37^{\circ} \mathrm{C}$. The spent culture medium was removed and replaced by adding $50 \mu \mathrm{l}$ of staining solution (prepared as $10 \mathrm{~mL}$ of PBS containing $20 \mu \mathrm{L}$ CellRox Orange stock and $2 \mu \mathrm{l}$ of Hoechst solution) to each well and then incubated at $37^{\circ} \mathrm{C}$ for $30 \mathrm{~min}$. The cell's images were acquired with a Molecular Devices ImageXpress ${ }^{\circledR}$ Micro XLS microscope (CA, USA) using TRITC, DAPI filters, and $\times 40$ objective. The images were later analyzed using a MetaXpress 6 software (Cell Scoring Module application).

\section{Genotoxicity}

To explore the genotoxicity of M. capensis extract, Vero cells were seeded in a 96-well plate at a density of 3000 cells per well and allowed to attach overnight and then exposed with plant extract at various concentrations $(12.5,25,50,100$, and $200 \mu \mathrm{g} / \mathrm{ml})$ while Griseofulvin, $(100 \mu \mathrm{M})$ and Etoposide $(50 \mu \mathrm{M})$ were used as positive controls. After $48 \mathrm{~h}$ of incubation, the spent culture medium was removed by aspiration and then replaced with $4 \%$ formaldehyde in PBS to fix the cells. The fix solution was removed and replaced with PBS containing 2 drops/ml of NucRed dye. Thereafter, the cell's images were acquired $(\times 20)$ by a Molecular Devices ImageXpress ${ }^{\circledR}$ Micro XLS microscope (CA, USA) using Cy5 filters. The data were analyzed using micronucleus assay software module.

\section{Ferric reducing antioxidant potential (FRAP) assay}

Briefly, FRAP assay was measured according to the method described by Odeyemi [12] with some modifications. FRAP reagent was freshly prepared by mixing $20 \mathrm{ml}$ of sodium acetate buffer ( $30 \mathrm{mM}$; pH 3.6), $2.5 \mathrm{ml}$ of tripyridyltriazine (TPTZ) solution (prepared as $10 \mathrm{mM}$ TPTZ in $40 \mathrm{mM} \mathrm{HCl}), 2 \mathrm{ml}$ of ferric chloride solution $(20 \mathrm{mM})$, and $2 \mathrm{ml}$ of distilled water. The solution was incubated at $37^{\circ} \mathrm{C}$ for $15 \mathrm{~min}$ before use. To $50 \mu \mathrm{l}$ of plant extract (prepared at $6.25,12.5,25,50,100$, and $200 \mu \mathrm{g} / \mathrm{ml}$ ) or positive control (Trolox, $100 \mu \mathrm{M}$ ) in the well of a 96-well plate, $200 \mu \mathrm{l}$ of freshly prepared FRAP reagent was added. The resulting mixture was incubated at $37^{\circ} \mathrm{C}$ for $30 \mathrm{~min}$ after which the absorbance was measured at $593 \mathrm{~nm}$.

\section{Statistical analysis}

The analysis was performed using Graph Pad Prism (version 5.01), and the test of significance was determined using Student's t-test

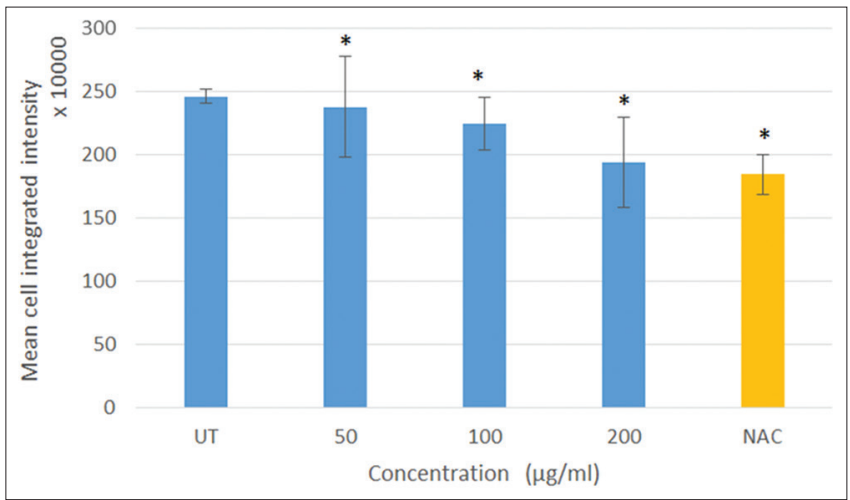

Fig. 2: Reactive oxygen species levels in tert-butyl hydroperoxide (TBHP) treated MRHF cells. Cells were treated with methanol extract of Miscanthus capensis at the indicated concentrations for $24 \mathrm{~h}$ and then exposed to TBHP to induce oxidative stress. Data are presented as the mean cellular integrated intensity and are thus independent of cell density. Higher values thus represent increased oxidative stress. *Significant difference $(p<0.05)$ compared to the untreated control. TBHP: Tert-Butyl hydroperoxide, NAC: N-Acetylcysteine, UT: untreated control

(two-tailed). Replicate values for each test compound were compared with replicate values of the negative controls. The level of significance ranged from $\mathrm{p}<0.001$ to $\mathrm{p}<0.05$.

\section{RESULTS AND DISCUSSION}

The reliability of the medicinal plant for its usage is evaluated by correlating the phytochemical compounds with their biological activities. Table 1 revealed the result of the GC-MS analysis of $M$. capensis methanol extract. A total of 77 compounds were identified. The major compounds were rosifoliol (33.66\%), 9, 12-Octadecadienoic acid (Z,Z)-, methyl ester (8.1\%), humulane-1, 6-dien-3-ol (7.48\%) alpha--cadinol (7.44\%), and carotol (5.78\%) while other main components in the extract were detected in a lower percentage. However, many of these identified constituents have been found to possess several pharmacological activities. Among them include 9, 12-0ctadecadienoic acid (Z,Z)-, methyl ester, a fatty acid methyl ester detected in M. capensis methanol extract has been showed to exhibit antibacterial activity [13]. $\alpha$-cadinol a sesquiterpene found in the extract of the understudy plant reported to possess antifungal and as hepatoprotective agents $[14,15]$. Carotol an alcohol sesquiterpene detected in high amount of the $M$. capensis extract reported to be involved in allelopathic interactions expressing activity such as antifungal and insecticidal agents [16]. n-Hexadecanoic acid, an ester compound of fatty acid reported to 
possesses various activities such as antioxidant, 5-alpha-reductase inhibitor, anti-androgenic, and hypocholesterolemic $[17,18]$. Oleic acid, one of the compounds identified in the extract is known to exhibit promising anticancer properties [19]. Caryophyllene oxide has also been found to be used as a preservative in cosmetics, foods, and drugs [20]. In addition, it has also been reported for its antifungal potential [21]. Spathulenol, one of the compounds detected in the methanol extract of $M$. capensis has been found to exhibit anti- inflammatory and antimicrobial activities [22]. It has also been found to inhibit the growth of Proteus mirabilis and Staphylococcus aureus which are the major bacteria associated with skin infections [23]. However, it is worth mentioning that the pharmacological activities of other compounds detected in the methanol extract of $M$. capensis are yet to be investigated. It could be concluded from this study that methanol extract of $M$. capensis composed of various bioactive compounds that are known to exhibit various biological activities.

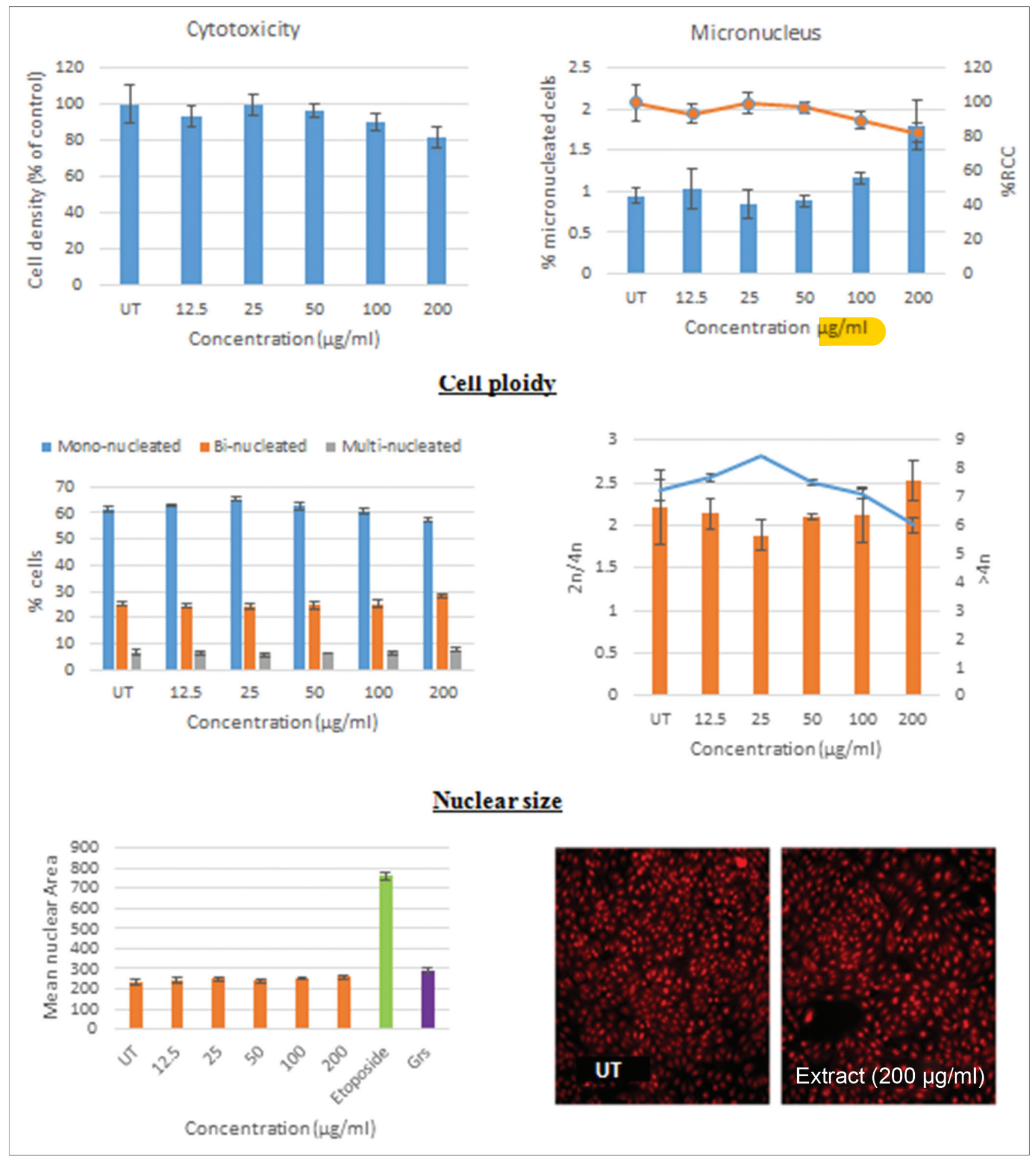

Fig. 3: Micronucleus formation and nuclear parameters of Vero cells treated with different concentrations of Miscanthus capensis. Cytotoxicity is measured as decrease in the number of cells relative to the untreated (UT) control (also referred to as \% relative cell count) 


\section{Cytotoxicity and mode of cell death}

For medicinal plant to be useful in clinical application, the preparation must not be interfered with normal physiological pathways and as well not toxic to the host cells or target organism. In this study, the cytotoxic effect of $M$. capensis methanol extract was evaluated by Molecular Devices ImageXpress ${ }^{\circledR}$ Micro XLS analysis. The results of the cytotoxicity and mode of cell death against MRHF cell lines are shown in Fig. 1. M. capensis extract exhibited no meaningful cytotoxic effect on MRHF cells at all the tested concentrations. In comparison, treatment of MHRF cells with the extract produced growth inhibition with a concentration-dependent reduction in the percentage of live cells counts compared to the trend seen with untreated (UT) control (100\%) (Fig. 1). On the contrary, it was also observed that there was a small but statistically significant increases in apoptosis as revealed by Annexin V-FITC at all the tested concentrations but physiological relevance doubtful. This suggests that $M$. capensis extract exhibited anti-proliferation rather than causing cell death. Therefore, the use of this plant in traditional medicine needs to be carefully monitored. It is imperative to note that no report of toxicity has been documented for the traditional use of M. capensis. However, it is also worth noting that cellular toxicity does not necessarily equate to whole animal toxicity due to possible interactions in the gut and bioavailability issues.

\section{The RoS levels}

ROS accumulates in cells as a result of thermal stress thereby leading to oxidative damage of tissue, and consequently, accelerated death of organisms $[24,25]$. To evaluate the effect of M. capensis extract on ROS levels, we examined its ability to reduce ROS levels in MRHF cells. The results (Fig. 2) showed that ROS level was lowered in the MRHF cells when exposed to the extract in a dose-dependent manner. However, the reduction of ROS levels by the extract at the tested concentrations (50, 100 , and $200 \mu \mathrm{g} / \mathrm{ml}$ ) was greater when compared to the UT control. Neither the extract nor the UT control exhibited a better reduction of ROS levels than the positive control, NAC. Nonetheless, studies have revealed that plant extracts decreased ROS generation due to flavonoid, phenolic, and terpenoid [26,27]. Arora et al. [28] reported that polyphenols have antioxidants with strong ability to attenuating ROS-induced oxidative damage. Therefore, the decline in ROS levels by the extract of $M$. capensis may be linked to the presence of the several compounds observed in the extract, thus suggesting an in vitro antioxidant activity of this plant extract. It is worth noting that this study shows for the first time the potential role of $M$. capensis extract in attenuating ROS levels, suggesting its possible use to prevent the rise of ROS levels and the consequent oxidative damage.

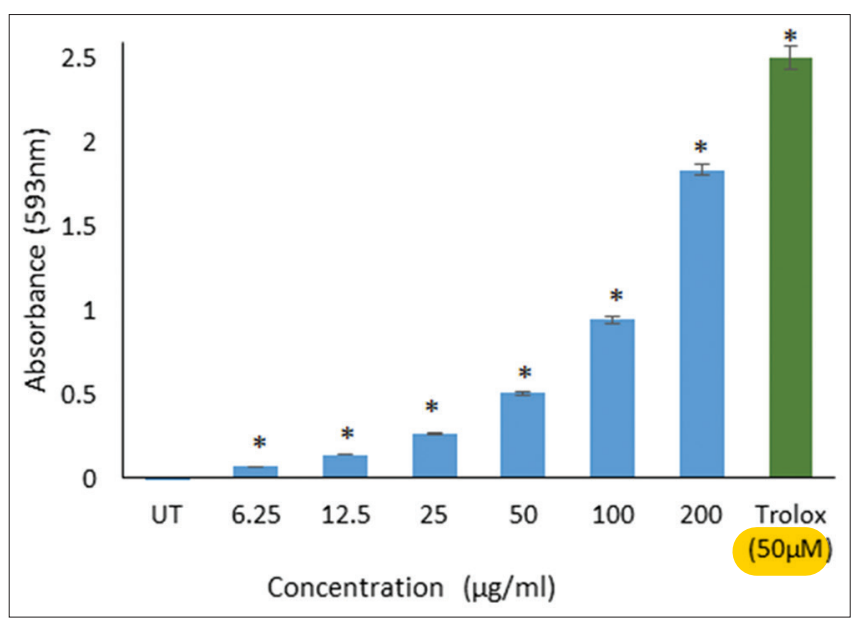

Fig. 4: Ferric reducing the antioxidant potential of the methanol extract of Miscanthus capensis. Dose data represent the absorbance at $593 \mathrm{~nm}$ after a $30 \mathrm{~min}$ incubation with the ferric reducing power reagent. *Significant difference $(p<0.05)$ compared to the untreated (UT) control

\section{Genotoxicity}

Fig. 3 shows the results of the genotoxic effect of M. capensis extract in Vero cells using the macronucleus assay. This assay is reliably used to detect test sample-induced chromosome damage, such as DNA strand breaks (clastogenic) and chromosome loss, often due to aberrant chromosome segregation (aneugenic). By scoring the formation of DNA fragments in the cytoplasm (micronuclei), one can evaluate the potential of a test sample to induce DNA damaged or chromosome loss. In the present study, the extract exhibited non-cytotoxic toward Vero cells and no significant increase in micronucleus formation was observed (Fig. 3). This was corroborated by a significant decrease in the number of bi- and multinucleated cells with the corresponding decrease in the nuclear size, suggesting that the extract is not considered as genotoxic at the tested concentrations investigated in this study. However, there was a slight difference in macronucleus formation between the UT control cells and the different concentrations of $M$. capensis extract. The positive controls, Etoposide and Griseofulvin induced DNA damage in Vero cells and the DNA area (nuclear size) were significantly increased. These results of Etoposide and Griseofulvin are expected as they have been used for decades as classical DNA-damaging agents. To the best of our knowledge, this is the first report of the evaluation of the genotoxic effect of the M. capensis extract using the micronucleus assay. These results are rather reassuring about the safety of the extract but should be confirmed by further in-depth investigations.

\section{FRAP assay}

The FRAP assay measures the antioxidant potential in samples through the reduction of ferric to ferrous iron by antioxidants present in the sample [29]. To assess the antioxidant activity of M. capensis extract, we investigate its reducing ability. The result of this assay shows that the extract possessed considerable FRAP values in a concentrationdependent manner (Fig. 4). At the maximum concentration tested in this study $(200 \mu \mathrm{g} / \mathrm{ml})$, the extract displayed remarkable FRAP value which was higher compared to the UT control. In addition, Trolox, (positive control), demonstrated better ferric reducing capacity than both the extract and UT control. However, several lines of studies have indicated that the ability of a compound to convert ferric iron into ferrous is a form of a good indicator of antioxidant potential [30,31]. This ferric reducing capacity of a compound has been attributed to the presence of bioactive components in the plant extracts. This observation is also in accordance with Jagadish et al. [32] who reported a strong relationship between bioactive components and antioxidant activity. Therefore, it is reasonable to suggest that the higher FRAP values exhibited by the understudy extract might be a combination of the role played by the different groups of bioactive components. Interestingly, the reducing ability of the understudy extract does correlate with the results obtained for reduction of ROS levels in MRHF cells, therefore suggests that the extract may be considered as a sustainable source of antioxidants to supplement the endogenous oxidative stress defense system in humans.

\section{CONCLUSION}

The present study revealed that methanol extract of M. capensis showed a maximum amount of bioactive components as confirmed by the GC/ MS study along with tremendous antioxidant activities as shown by FRAP and reduction of ROS levels in MRHF cells. However, the extract also demonstrated no meaningful cytotoxicity and genotoxic effects which further support the safe use of the plant for human consumption but should be confirmed by further in-depth investigations. These results would positively help to discover $M$. capensis roots for potential use in eradicating skin and oxidative stress-related diseases.

\section{ACKNOWLEDGMENTS}

The authors are grateful to the National Research Foundation (NRF) and the University of Mpumalanga, for financial support to conduct this research.

\section{AUTHORS' CONTRIBUTIONS}

The authors contributed equally. 


\section{CONFLICTS OF INTEREST}

The authors declare that they have no conflicts of interest regarding the publication of this paper.

\section{FUNDING}

This work was funded by the National Research Foundation (NRF) South Africa (Grant no: 105161).

\section{REFERENCES}

1. Luo H, Yamamoto Y, Liu Y, Jung JS, Kahng HY, Koh YJ, et al. The in vitro antioxidant properties of Chinese highland lichens. J Microbiol Biotechnol 2010;20:1524-8.

2. Hwang HS, Winkler Moser JK, Liu SX. Structural Polymerization, effect of lignans and sesamol on Temperature of soybean oil at frying. J Am Oil Chem Soc 2012;89:1067-76.

3. Choi JS, Chung HY, Jung HA, Park HJ, Yokozawa T. Comparative evaluation of antioxidant potential of alaternin (2-hydroxyemodin) and emodin. J Agric Food Chem 2000;48:6347-51.

4. Gupta-Elera G, Garrett AR, Robison RA, O'Neill KL. The role of oxidative stress in prostate cancer. Eur J Cancer Prev 2012;21:155-62.

5. Stohs SJ. The role of free radicals in toxicity and disease. J Basic Clin Physiol Pharmacol 1995;6:205-28.

6. Siddiqui IA, Adhami VM, Saleem M, Mukhtar H. Beneficial effects of tea and its polyphenols against prostate cancer. Mol Nutr Food Res 2006;50:130-43

7. Costa DA, de Oliveira GA, Lima TC, dos Santos PS, de Sousa DP, de Freitas RM, et al. Anticonvulsant and antioxidant effects of cyano-carvone and its action on acetylcholinesterase activity in mice hippocampus. Cell Mol Neurobiol 2012;32:633-40.

8. da Rocha ML, Oliveira LE, Patrício Santos CC, de Sousa DP, de Almeida RN, Araújo DA, et al. Antinociceptive and antiinflammatory effects of the monoterpene $\alpha, \beta$-epoxy-carvone in mice. J Nat Med 2013;67:743-9.

9. Jafari S, Saeidnia S, Abdollahi M. Role of natural phenolic compounds in cancer chemoprevention via regulation of the cell cycle. Curr Pharm Biotechnol 2014;15:409-21.

10. Unnati S, Ripal S, Sanjeev A, Niyati A. Novel anticancer agents from plant sources. Chin J Nat Med 2013;11:16-23.

11. Sagbo IJ, Otang Mbeng W. Plants used for cosmetics in the Eastern Cape Province of South Africa: A case study of skin care. Phoogn Rev 2018;12:139-56.

12. Odeyemi S. A Comparative Study of the in vitro Antidiabetic Properties, Mechanism of Action and Cytotoxicity of Albuca setosa and Albuca bracteata Bulb Extracts. [PhD Thesis]. Department of Biochememistry and Microbiology: University of Fort Hare; 2016.

13. Lima LA, Johann S, Cisalpino PS, Pimenta LP, Boaventura MA. In vitro antifungal activity of fatty acid methyl esters of the seeds of Annona cornifolia A.St.-Hil. (Annonaceae) against pathogenic fungus Paracoccidioides brasiliensis. Rev Soc Bras Med Trop 2011;44:777-80.

14. Ho CL, Liao PC, Wang EI, Su YC. Composition and antifungal activities of the leaf essential oil of Neolitsea parvigemma from Taiwan. Nat Prod Commun 2011;6:1357-60.

15. Tung YT, Huang CC, Ho ST, Kuo YH, Lin CC, Lin CT, et al. Bioactive phytochemicals of leaf essential oils of Cinnamomum osmophloeum prevent lipopolysaccharide/D-galactosamine (LPS/D-GalN)-induced acute hepatitis in mice. J Agric Food Chem 2011;59:8117-23.

16. Wieczorek P. Structure of natural antibiotic CP-47,444. Chemik 2006;59:55-9.

17. Dandekar R, Fegade B, Bhaskar VH. GC-MS analysis of phytoconstituents in alcohol extract of Epiphyllum oxypetalum leaves. J Pharmacogn Phytochem 2015;4:149-54.

18. Soosairaj S, Dons T. Bio-active compounds analysis and characterization in ethanolic plant extracts of Justicia tranquebariensis L. (Acanthaceae)using GC-MS. Int J ChemTech Res 2016;9:260-5.

19. Hase JG, Deshumkh KK, Pokharkar DR, Gaje RT, Phatanagre DN. Phytochemical studies on Nerium oleander L. using GC-MS. Int J Pharmacogn Phytochem Res 2017;9:885-91.

20. Ashraf A, Sarfraz RA, Rashid MA, Mahmood A, Shahid M, Noor N, et al. Chemical composition, antioxidant, antitumor, anticancer and cytotoxic effects of Psidium guajava leaf extracts. Pharm Biol 2016;54:1971-81.

21. Yang D, Michel L, Chaumont JP, Millet-Clerc J. Use of caryophyllene oxide as an antifungal agent in an in vitro experimental model of onychomycosis. Mycopathologia 1999;148:79-82.

22. Prakasia P, Nair A. Chemical fingerprint of essential oil components from fresh leaves of Glycosmis pentaphylla (Retz.) Correa. Pharm Innov J 2015;3:50-6.

23. Durán P, Maria JA, José MB, James RB, Collado B, Isidro Rosario G, et al. Biological activity of natural sesquiterpenoids containing a gem Dimethylcyclopropane unit. Nat Prod Rep 2012;32:1-3.

24. Ishii N, Senoo-Matsuda N, Miyake K, Yasuda K, Ishii T, Hartman PS, et al. Coenzyme Q10 can prolong C. elegans lifespan by lowering oxidative stress. Mech Ageing Dev 2004;125:41-6.

25. Zhuanhua W, Xiaoli M, Jiao L, Xiaodong C. Peptides from sesame cake extend healthspan of Caenorhabditis elegans, via upregulation of skn-1, and inhibition of intracellular ROS levels. Exp Gerontol 2016;82:139-49.

26. Kumar GP, Khanum F. Neuroprotective potential of phytochemicals. Pharmacogn Rev 2012;6:81-90.

27. Olajuyigbe OO, Afolayan AJ. Phenolic content and antioxidant property of the bark extracts of Ziziphus mucronata willd. Subsp. Mucronata willd. BMC Complement Altern Med 2011;11:130.

28. Arora A, Byrem TM, Nair MG, Strasburg GM. Modulation of liposomal membrane fluidity by flavonoids and isoflavonoids. Arch Biochem Biophys 2000;373:102-9.

29. Fernandes RP, Trindade MA, Tonin FG, Lima CG, Pugine SM, Munekata PE, et al. Evaluation of antioxidant capacity of 13 plant extracts by three different methods: Cluster analyses applied for selection of the natural extracts with higher antioxidant capacity to replace synthetic antioxidant in lamb burgers. J Food Sci Technol 2016;53:451-60

30. Alia M, Horcajo C, Bravo L, Goya L. Effect of grape antioxidant dietary fiber on the total antioxidant capacity and the activity of liver antioxidant enzymes in rats. Nutr Res 2003;23:1251-67.

31. Rao AS, Reddy SG, Babu PP, Reddy AR. The antioxidant and antiproliferative activities of methanolic extracts from njavara rice bran. BMC Complement Altern Med 2010;10:4.

32. Jagadish LK, Krishnan VV, Shenbhagaraman R, Kaviyarasan V. Comparative study on the antioxidant, anticancer and antimicrobial property of Agaricus bisporus Imbach before and after boiling. Afr J Biotechnol 2009;8:654-61. 